\title{
Pengaruh Konsentrasi Xanthan Gum (1,5\% dan 2\%) terhadap Karakteristik Fisika dan Kimia Sereal Daun Kelor dengan Pengisi Susu Soya dan Susu Skim
}

\author{
Karina Citra Rani ${ }^{1}$, Nikmatul Ikhrom Eka Jayani ${ }^{2}$, Marvela Christabel Renata ${ }^{3}$, Elisabeth \\ Regina Oetama ${ }^{3}$ dan Nani Parfati ${ }^{1}$ \\ 'Departemen Farmasetika, Fakultas Farmasi Universitas Surabaya, Surabaya, Indonesia \\ ${ }^{2}$ Departemen Biologi Farmasi, Fakultas Farmasi Universitas Surabaya, Surabaya, Indonesia \\ ${ }^{3}$ Fakultas Farmasi, Universitas Surabaya, Surabaya, Indonesia \\ Korespondensi: Karina Citra Rani \\ Email: karinacitrarani@staff.ubaya.ac.id
}

Submitted : 02-05-2021, Revised : 09-06-2021, Accepted : 26-06-2021

\begin{abstract}
ABSTRAK: Daun kelor potensial dikembangkan menjadi produk nutraseutikal dalam bentuk sereal. Granul sereal daun kelor diformulasikan menggunakan suspending agent xanthan gum dan kombinasi pengisi susu soya-susu skim. Penelitian ini bertujuan untuk menganalisis pengaruh perbedaan konsentrasi xanthan gum 1,5\% (F1) dan 2\% (F2) terhadap karakteristik fisika dan kimia sereal daun kelor. Metode yang digunakan dalam pembuatan granul sereal daun kelor adalah granulasi basah. Hasil evaluasi karakteristik granul menunjukkan kedua formula granul berwarna hijau tua, rasa manis, dan aroma melon. Granul dapat mengalir dengan baik ditinjau dari nilai Rasio Hausner dan indeks kompresibilitas formula 1 dan 2 yaitu 1,09 \pm 0,10 dan 11,52 $\pm 3,81 \%$ serta 1,13 $\pm 0,07$ dan 11,19 \pm 5,64\%. Kandungan lembab granul juga memenuhi persyaratan yaitu $2,64 \pm 0,43 \%$ pada formula 1 dan $2,84 \pm 0,28 \%$ pada formula 2 . Setelah rekonstitusi, granul sereal terdispersi dalam bentuk suspensi halus berwarna hijau kecoklatan, rasa manis, dan aroma melon. Peningkatan konsentrasi xanthan gum pada formula 2 berpengaruh signifikan terhadap peningkatan waktu dispersi dan viskositas dibandingkan formula 1. Waktu dispersi formula 1 dan 2 masing-masing adalah 8,44 dan 9,17 detik, sedangkan viskositas formula 1 dan 2 adalah 136,93 dan 275,58 cps. Konsentrasi xanthan gum yang lebih tinggi pada formula 2 menghasilkan volume sedimentasi yang lebih tinggi $(\mathrm{F}=1)$ dan stabilitas dispersi yang lebih baik dibandingkan formula $1(\mathrm{~F}<1)$.
\end{abstract}

Kata kunci: Kelor; Moringa oleifera; nutraseutikal; sereal; xanthan gum

ABSTRACT: Moringa leaves are potential to be developed into nutraceutical products in cereals form to meet daily nutritional requirements and improve health. Moringa leaf cereal in this study was developed into granules using xanthan gum as suspending agent and a combination of soya-skim milk as fillers. This study aims to analyze the effect of xanthan gum concentrations of 1.5\% (F1) and 2\% (F2) on the physical and chemical characteristics of Moringa leaf cereal. The wet granulation method was applied in the production of Moringa leaf cereal granules. The results of the granule characteristics implied that both granule formulas were dark green, sweet taste, and melon aroma. Granules exhibited good flowability according the results of Hausner's ratio and compressibility index of formulas 1 and 2, respectively $1.09 \pm 0.10$ and $11.52 \pm 3.81 \%$, then $1.13 \pm 0.07$ and $11.19 \pm 5.64 \%$. The moisture content of the granules also met the requirements, which were $2.64 \pm 0.43 \%$ in formula 1 and $2.84 \pm 0.28 \%$ in formula 2 . After reconstitution, cereal granules were dispersed as a fine suspension of brownish green color, sweet taste, and melon aroma. The increase of xanthan gum concentration in formula 2 implied a significant effect on increasing the dispersion time and viscosity, compared to formula 1. The dispersion time of formula 1 and 2 were 8.44 and 9.17 seconds, hence the viscosity of formulas 1 and 2 were 136.93 and 275.58 cps, respectively. The higher xanthan gum concentration in formula 2 resulted in a higher sedimentation volume $(F=1)$ and better dispersion stability than formula 1 ( $F<1)$.

Keywords: cereal; kelor; Moringa oleifera; nutraceutical; xanthan gum 


\section{Pendahuluan}

Tanaman kelor mengandung nutrisi penting untuk pemenuhan gizi yaitu asam amino esensial, karbohidrat, mineral sebagai makroelemen (kalsium, magnesium, potassium, fosfor, dan sulfur), mineral sebagai mikroelemen (besi, zink, tembaga, dan mangan), asam lemak, omega-6, vitamin, klorofil, antioksidan (lutein, karotenoid, zeatin, kuersetin, kaempferol), dan beta sitosterol [1]. Bagian dari tanaman kelor yang memiliki kandungan nutrisi tinggi adalah daun. Daun kelor dilaporkan mengandung protein (19-29\%), serat (16-24\%), lemak, karbohidrat, mineral, kalsium, magnesium, fosfor, potassium, tembaga, besi, sulfur, asam oksalat, vitamin A, vitamin B (kolin), vitamin B1 (thiamin), vitamin B2 (riboflavin), vitamin B3, vitamin C, dan vitamin E [2]. Penggunaan daun kelor sebagai sumber pangan di Indonesia masih sangat terbatas. Pengembangan produk nutraseutikal daun kelor merupakan salah satu sarana diversifikasi pangan untuk memenuhi kebutuhan nutrisi dan memberikan manfaat kesehatan. Produk nutraseutikal daun kelor juga dinilai ekonomis untuk dikonsumsi oleh seluruh penduduk Indonesia, termasuk penduduk dengan pendapatan per kapita yang rendah [3]. Berdasarkan data tersebut, dapat disimpulkan bahwa produk nutraseutikal daun kelor memiliki prospek yang baik untuk dikembangkan sebagai alternatif produk pangan di Indonesia.

Salah satu bentuk produk nutraseutikal berbasis daun kelor yang dapat dikembangkan adalah sereal daun kelor. Sereal dan komponen penyusunnya dapat dikategorikan sebagai nutraseutikal karena memiliki peran dalam memenuhi kebutuhan serat, protein, energi, mineral, vitamin, dan antioksidan yang diperlukan untuk kesehatan tubuh manusia [4]. Daun kelor segar diproses terlebih dahulu menjadi bentuk serbuk untuk kemudian diformulasi menjadi granul. Serbuk daun kelor dipilih sebagai material awal pengembangan produk sereal karena memiliki kandungan lembab yang rendah, sehingga stabili- tas produk akhir dapat menjadi lebih terjamin. Hasil penelitian juga menunjukkan bahwa kandungan nutrisi pada daun kelor setelah diubah menjadi serbuk kering masih mampu memenuhi kebutuhan nutrisi harian manusia [2].

Pengembangan produk sereal daun kelor dapat dilakukan dengan metode granulasi basah pada suhu pengeringan tidak melebihi $60^{\circ} \mathrm{C}$ untuk mempertahankan stabilitas kandungan proksimat dan antioksidan [5]. Pengembangan sediaan dalam bentuk granul dapat memperbaiki karakteristik fisik serbuk seperti karakteristik aliran, mencegah segregasi komponen, dan meningkatkan keseragaman kandungan [6]. Karakteristik penting yang harus diperhatikan dalam formulasi sereal adalah struktur, tekstur, dan kekentalan sereal. Suspending agent merupakan komponen dalam formula sereal daun kelor yang berperan utama dalam mempengaruhi struktur, tekstur, kekentalan, dan stabilitas sereal setelah direkonstitusi [7]. Xanthan gum merupakan salah satu jenis suspending agent yang menunjukkan karakteristik aliran pseudoplastis, serta mampu menghasilkan dispersi yang kental. Viskositas hasil dispersi xanthan gum dalam air menunjukkan stabilitas yang sangat baik pada rentang $\mathrm{pH}$ dan temperatur yang luas [8]. Oleh karena itu, xanthan gum digunakan sebagai suspending agent dalam pengembangan sereal daun kelor pada penelitian ini.

Konsentrasi xanthan gum dalam formula sereal daun kelor merupakan salah satu variabel yang berpengaruh terhadap karakteristik fisika dan kimia sereal daun kelor [9]. Pada penelitian sebelumnya telah dilakukan pengembangan sereal daun kelor dengan konsentrasi xanthan gum 0,$3 ; 0,5$; dan 1,0\%, namun hasil evaluasi menunjukkan bahwa viskositas sereal terlalu encer dan partikel serbuk daun kelor mudah mengendap [10]. Oleh karena itu, dalam penelitian ini dilakukan pengembangan formula dengan peningkatan konsentrasi xanthan gum sebagai suspending agent, yaitu 1,5\% (F1) dan 2,0\% (F2).

Pengisi juga merupakan komponen lain dalam 
formula yang berperan mempengaruhi tekstur dan kandungan nutrisi sereal. Susu soya dan susu skim merupakan kombinasi yang efektif digunakan sebagai pengisi dalam formulasi sereal, karena dapat meningkatkan penerimaan sensori, tekstur, kandungan protein, dan kandungan lemak produk makanan. Berdasarkan fakta tersebut, kombinasi susu sereal dan susu skim digunakan sebagai pengisi formula sereal dalam penelitian ini [11]. Penelitian ini bertujuan untuk mengoptimasi pengaruh perbedaan konsentrasi xanthan gum 1,5 \% (F1) dan 2,0\% (F2) terhadap karakteristik fisik dan kimia sereal daun kelor dengan pengisi kombinasi susu soya dan susu skim.

Sereal daun kelor yang dihasilkan dalam penelitian ini dilakukan evaluasi meliputi karakteristik fisik granul dan karakteristik sereal setelah direkonstitusi (organoleptis, waktu dispersi, pH, viskositas, dan sifat alir). Pemenuhan terhadap persyaratan SNI susu sereal dilakukan melalui analisis proksimat dan kandungan logam sesuai persyaratan SNI 01-4270-1966 untuk susu sereal [12]. Analisis proksimat yang dilakukan meliputi penentuan kadar air, kadar abu, protein, lemak, karbohidrat, serat kasar sesuai persyaratan. Sementara itu, kandungan logam yang dianalisis meliputi $\mathrm{Pb}$ dan $\mathrm{Cu}$. Evaluasi terhadap kandungan lembab granul sereal daun kelor selama penyimpanan 28 hari pada suhu kamar $\left(25-30^{\circ} \mathrm{C}\right)$ juga dilakukan untuk memperoleh profil stabilitas fisik sereal.

\section{Bahan dan Metode}

\subsection{Bahan}

Bahan utama yang digunakan dalam penelitian ini adalah daun kelor (Moringa oleifera L.) segar yang dipanen dari Desa Bogo, Bojonegoro. Daun kelor telah dideterminasi pada Pusat Informasi dan Pengembangan Obat Tradisional (PIPOT) Universitas Surabaya dengan surat keterangan determinasi No. 1412/D.T/X/2019. Bahanbahan tambahan lain yang digunakan untuk pembuatan susu sereal daun kelor ini antara lain tepung garut f.g (Healthy Choice-PT. Indospirit Natura, Jakarta), xanthan gum f.g (Neimenggu Fufeng Biotechnologies Co., Ltd, Jienchuan District Economic, China), stevia f.g (diperoleh dari PT. Jamu Iboe, Sidoarjo), sukrosa (PT. Sugar Group Companies, Jakarta), krimer nabati (MAXCreamer®-PT. Sari Incofood Corporation, Medan), natrium benzoat p.g (Emerald Kalama Chemical, B.V, Rotterdam, Netherlands), telur, susu soya bubuk Mahkota (CV. Bintang Sentosa, Semarang), susu skim bubuk f.g (NZMP Skimmilk Powder yang diproduksi PT. Fonterra Brands Indonesia, Jakarta), bubuk melon (PT. KH Roberts, Buroh Lane, Singapura), dan bubuk strawberry (PT. KH Roberts, Buroh Lane, Singapura).

\subsection{Alat}

Alat-alat yang digunakan dalam penelitian ini meliputi timbangan analitik Ohaus PioneerSoehnle (Darmstadt, Jerman), timbangan digital Ohaus Scout Pro SPS202F (Darmstadt, Jerman), pengayak nomor mesh 10, 16 dan 100 (Haan, Jerman), mixer Electrolux® (Stockholm, Swedia), blender Philips® HR 2116 (Batam, Indonesia), Retsch Vibrator tipe AS200 basic (Haan, Jerman), pengayak US Standard Sieve Series (Endecotts Test SievesLimited, Haan, Jerman), moisture content apparatus OHAUS MC MB45 (Shanghai, China), tapping density Pharma Test D-63512 Hainburg tipe PT TD200 (Hainburg, Jerman), corong standar (Surabaya, Indonesia), statif (Surabaya, Indonesia), stopwatch Q\&Q (Tokyo, Jepang), pH meter Horiba LAQUA-PH1100 (Kyoto, Jepang, viskometer cup and bob tipe stormer 80202 (Ohio, USA), Tray dryer MMM Medcenter (Munchen, Jerman), dan oven Memmert 854 Schwabach W (Buechenbach, Jerman).

\subsection{Formulasi sereal daun kelor}

\subsubsection{Penyiapan serbuk daun kelor}

Daun kelor segar dipanen dari Desa Bogo, Kecamatan Kapas, Kabupaten Bojonegoro, Jawa Timur. Daun kelor kemudian dicuci dengan air 
mengalir, disortasi, dan ditiriskan. Daun kelor yang telah disortasi selanjutnya dikeringkan dengan cara diangin-anginkan selama 7 hari pada suhu kamar $\left(25-30^{\circ} \mathrm{C}\right)$ hingga kandungan lembab $<10 \%$ [13]. Daun kelor kering tersebut dihancurkan dengan menggunakan blender menjadi serbuk, kemudian diayak dengan ayakan nomor mesh 100.

\subsubsection{Pembuatan granul sereal daun kelor}

Sereal daun kelor diformulasi dalam bentuk granul dengan metode granulasi basah. Seluruh komponen formula seperti yang tertera pada Tabel 1 ditimbang sesuai dengan jumlah yang ditentukan. Serbuk daun kelor, tepung garut, xanthan gum, sukrosa, stevia, krimer nabati, susu soya, dan susu skim dicampur kering di dalam low shear mixer selama 5 menit. Flavor melon dan flavor strawberry ditambahkan ke dalam campuran tersebut, kemudian diaduk selama 5 karakteristik fisik dan kimia sereal.

\subsection{Evaluasi sereal dau kelor}

\subsubsection{Evaluasi karakteristik fisik granul}

Evaluasi karakteristik fisik granul sereal daun kelor meliputi organoleptis, distribusi ukuran partikel, bobot jenis nyata, bobot jenis mampat, rasio Hausner, indeks kompresibilitas, kecepatan alir, sudut istirahat, dan kandungan lembab. Pengamatan organoleptis dilakukan terhadap parameter warna, rasa, dan bau sereal daun kelor [14].

Evaluasi distribusi ukuran partikel granul sereal daun kelor dilakukan dengan metode pengayakan. Evaluasi dilakukan dengan meletakkan 100 g granul pada pengayak paling atas dari satu seri pengayak yaitu dengan urutan no. mesh $20,30,50,60,80$, dan 100 . Satu seri pengayak tersebut diletakkan di atas instrumen Retsch Vibrator, kemudian digetarkan dengan

Tabel 1. Formula sereal daun kelor dengan variasi konsentrasi xanthan gum

\begin{tabular}{llll}
\hline Bahan & Fungsi & Formula 1 (F1, \%) & Formula 2 (F2, \%) \\
\hline Tepung daun kelor & Bahan aktif & 8 & 8 \\
Tepung garut & Thickening agent & 20 & 20 \\
Xanthan gum & Suspending agent & 1,5 & 2 \\
Sukrosa & Pemanis & 20 & 20 \\
Stevia & Pemanis & 3 & 3 \\
Krimer nabati & Flavour & 5 & 5 \\
Natrium Benzoat & Pengawet & 0,1 & 0,1 \\
Telur & Binder & 13 & 13 \\
Susu soya bubuk & Pengisi & 10 & 10 \\
Susu skim bubuk & Pengisi & 7,4 & 6,9 \\
Strawberry & Perisa & 5 & 5 \\
Melon & Perisa & 7 & 7 \\
\hline
\end{tabular}

menit. Telur ditambahkan sedikit demi sedikit ke dalam campuran sampai terbentuk massa granul yang lembab. Massa granul selanjutnya diayak menggunakan ayakan nomor mesh 10 dan dikeringkan dengan oven pada suhu $50^{\circ} \mathrm{C}$ selama \pm 3 jam, hingga tercapai kandungan lembab granul sekitar 2-4\%. Granul kering yang terbentuk diayak menggunakan ayakan nomor mesh 16, kemudian dilanjutkan untuk evaluasi frekuensi $60 \mathrm{~Hz}$ selama 20 menit. Setelah 20 menit, masing-masing pengayak dan granul yang terdapat di dalamnya ditimbang bobotnya dan dihitung bobot granul yang terdapat pada masing-masing pengayak dan pan penampung. Hasil yang diperoleh selanjutnya diolah untuk ditampilkan sebagai kurva distribusi ukuran partikel granul [15].

Pengukuran bobot jenis nyata dilakukan 
dengan menimbang granul sebanyak 40 g. Granul tersebut kemudian dituang ke dalam gelas ukur $100 \mathrm{ml}$ yang dimiringkan pada sudut $45^{\circ}$ dengan cepat menggunakan corong. Gelas ukur yang berisi granul digoyangkan dengan cepat untuk meratakan permukaan bahan dan mengukur volume granul. Bobot jenis nyata dapat dihitung dengan membagi bobot granul (40 g) dengan volume granul dalam gelas ukur tersebut [16].

Pengukuran bobot jenis mampat dilakukan dengan meletakkan $40 \mathrm{~g}$ granul di dalam gelas ukur pada instrumen tapped density tester. Instrumen kemudian dijalankan dan dilakukan pengamatan volume granul setiap interval 100 ketukan. Pengamatan dihentikan sampai tiga interval pengamatan secara berurutan menunjukan volume yang tetap. Bobot jenis mampat granul dihitung dengan membagi bobot granul dengan volume granul yang sudah mampat [16].

Hasil perhitungan bobot jenis nyata dan bobot jenis mampat kemudian digunakan untuk menghitung rasio Hausner dan indeks kompresibilitas granul sereal daun kelor. Nilai kedua parameter tersebut dapat digunakan untuk memprediksi karakteristik alir granul [17]. Rasio Hausner dapat dihitung dengan membagi bobot jenis mampat dengan bobot jenis nyata. Indeks kompresibilitas granul dihitung melalui persamaan berikut:

$$
\text { Compressibility index }=\frac{\text { Tapped density-Bulk density }}{\text { Tapped density }} \times 100 \%
$$

Kecepatan alir dan sudut istirahat granul ditentukan dengan metode flow through an orifice, menggunakan satu set corong standar dan statif. Sebanyak 100 g granul dituang ke dalam corong dengan dasar lubang corong ditutup menggunakan penutup standar. Tutup dasar lubang corong dibuka bersamaan dengan stopwatch dinyalakan. Waktu yang diperlukan granul untuk mengalir sampai granul dalam corong habis dicatat. Kecepatan alir dapat dihitung dengan membagi bobot granul dengan waktu yang dibutuhkan seluruh granul mengalir melewati corong. Penentuan sudut istirahat dapat dilakukan bersamaan dengan pengujian kecepatan alir. Tinggi timbunan granul yang terbentuk pada bidang datar di bawah corong (h) dan jari-jari alas kerucut (r) timbunan bahan tersebut diukur [18]. Sudut istirahat $(\alpha)$ granul dapat dihitung dengan persamaan berikut:

$$
\operatorname{tg} \alpha=\frac{h}{r}
$$

Pengukuran kandungan lembab granul dilakukan menggunakan moisture content analyzer hingga tercapai bobot konstan [19]. Granul sereal daun kelor sebanyak \pm 5 g diletakkan pada pan penampung di dalam instrumen kemudian diratakan permukaannya. Penutup instrumen ditutup dan instrumen dinyalakan dengan menekan tombol start. Proses pengeringan dilakukan pada suhu $\pm 100^{\circ} \mathrm{C}$ selama 10 menit. Persentase kandungan lembab granul yang ditunjukkan pada instrumen dicatat sebagai kandungan lembab granul.

\subsubsection{Evaluasi karakteristik sereal setelah rekonstitusi}

Evaluasi karakteristik sereal setelah rekonstitusi dilakukan dengan merekonstitusi 30 g sereal daun kelor (bobot untuk 1 kemasan) dengan $150 \mathrm{ml}$ aquapurificata hangat. Sereal yang telah terekonstitusi kemudian dievaluasi. Evaluasi yang dilakukan meliputi organoleptis, waktu dispersi, pH, viskositas, karakteristikaliran, dan volume sedimentasi. Evaluasi organoleptis sereal setelah direkonstitusi dilakukan dengan melakukan pengamatan warna, bau, dan rasa sediaan [20].

Granul sereal daun kelor sebanyak $30 \mathrm{~g}$ direkonstitusi dengan aquapurificata hangat (suhu sekitar $60^{\circ} \mathrm{C}$ ). Stopwatch disiapkan dan dihitung lama waktu yang dibutuhkan oleh sereal daun kelor menjadi suspensi yang homogen dengan pengadukan. Waktu yang dibutuhkan untuk seluruh granul terdispersi merata dalam aquapurificata dicatat sebagai waktu rekonstitusi sereal [21]. Dispersi granul sereal daun kelor dalam aquapurificata kemudian dilakukan 
pengukuran pH dengan menggunakan $\operatorname{Scott} \circledast \mathrm{pH}$ meter [22].

Viskositas dan sifat alir sereal daun kelor setelah direkonstitusi diamati dengan viskometer cup and bob tipe stormer. Sampel sereal sebanyak 400-600 ml disiapkan untuk pengujian ini, kemudian dilakukan pengamatan waktu yang dibutuhkan oleh bob untuk berputar sebanyak 100 putaran pada sediaan yang diuji. Berdasarkan data tersebut ditentukan laju geser (rate of shear) dan viskositas sediaan pada penambahan beban (shearing stress) tertentu, kemudian dibuat plot hubungan antara shearing stress dan rate of shear untuk menentukan karakteristik aliran sereal daun kelor [9].

Pengamatan volume sedimentasi sereal daun kelor dilakukan dengan menuangkan $25 \mathrm{ml}$ sereal yang telah direkonstitusi ke dalam gelas ukur $25 \mathrm{ml}$. Bagian atas gelas ukur kemudian ditutup dengan alumunium foil dan dilakukan pengocokan secara vertikal sebanyak 10 kali. Gelas ukur yang berisi sereal tersebut kemudian diletakkan di dalam tempat tertentu yang bebas goncangan dan dilakukan pengamatan volume sedimentasi (F) pada beberapa waktu. Interval waktu pengamatan yang dilakukan yaitu kondisi awal (0 menit), 15, 30, 45, 60, dan 120 menit [23].

\subsubsection{Analisis proksimat dan kandungan logam}

Analisis proksimat dan kandungan logam dilakukan pada sereal daun kelor yang dihasilkan dalam penelitian ini sesuai dengan persyaratan SNI susu sereal (SNI 01-4270-199). Analisis proksimat yang dilakukan meliputi kandungan karbohidrat, lemak, protein, serat kasar, abu, dan air. Sementara itu, kandungan logam yang ditentukan pada produk sereal meliputi logam $\mathrm{Pb}$ dan $\mathrm{Cu}[12]$.

\subsubsection{Evaluasi kandungan lembab sereal selama penyimpanan}

Kandungan lembab merupakan salah satu parameter penting yang menentukan stabilitas fisika dan kimia granul sereal daun kelor. Sereal daun kelor yang dihasilkan dikemas dalam kemasan sachet dengan bobot 30 g per sachet. Granul sereal yang telah dikemas tersebut kemudian disimpan pada suhu kamar (25$30^{\circ} \mathrm{C}$ ) selama 4 minggu. Pengamatan kandungan lembab granul sereal daun kelor dilakukan pada hari ke- $0,7,14,21$, dan 28.

\subsection{Analisis data}

Hasil evaluasi karakteristik fisik granul dilakukan analisis deskriptif dengan cara membandingkan hasil yang diperoleh dengan persyaratan karakteristikgranul pada kompendia. Selain itu, hasil evaluasi karakteristik sereal meliputi kandungan lembab, viskositas, waktu dispersi, dan $\mathrm{pH}$ dilakukan uji-t bebas untuk melihat perbedaan efek konsentrasi xanthan gum terhadap karakteristik sereal. Evaluasi mutu sediaan sereal daun kelor sesuai persyaratan SNI susu sereal (SNI 01-4270-1996) meliputi analisis proksimat dan kandungan logam dilakukan analisis secara deskriptif.

\section{Hasil dan pembahasan}

\subsection{Formulasi sereal daun kelor}

Daun kelor kering yang digunakan dalam penelitian ini memiliki kandunganlembabsebesar $7,08 \%$ setelah melalui proses pengeringan selama 7 hari pada suhu kamar. Kandungan lembab daun kelor kering tersebut sudah memenuhi persyaratan kandungan lembab yaitu $\leq 10 \%$ [24]. Daun kelor kering tersebut kemudian dihaluskan dengan blender menjadi serbuk dan diayak menggunakan pengayak mesh nomor 100. Daun kelor segar dan kering, serta serbuk daun kelor yang digunakan pada penelitian ini ditunjukkan pada Gambar 1. Serbuk daun kelor tersebut kemudian dicampur dengan bahan tambahan lainnya seperti yang tertera pada Tabel 1. Campuran masa serbuk tersebut dibentuk menjadi granul dengan metode granulasi basah.

\subsection{Karakteristik granul}

Hasil pengamatan organoleptis pada kedua formula granul sereal daun kelor menunjukkan 
Tabel 2. Hasil evaluasi karakteristik granul sereal daun kelor

\begin{tabular}{lllll}
\hline Parameter & \multicolumn{2}{l}{ Formula } & Persyaratan \\
\cline { 2 - 4 } & & F1 & F2 & Granul \\
\hline Organoleptis & Bentuk & Granul & Granul & Melon \\
& Aroma & Melon & Melon & Manis \\
& Rasa & Manis & Manis & Hijau \\
& Warna & Hijau & Hijau & $<20[16]$ \\
Fines (\%) & & $2,50 \pm 1,00$ & $2,00 \pm 0,81$ & $1,00-1,25[41]$ \\
Rasio Hausner & $1,09 \pm 0,10$ & $1,13 \pm 0,07$ & $10-20[41]$ \\
Kompresibilitas (\%) & $11,52 \pm 3,81$ & $11,19 \pm 5,64$ & $4-10[42]$ \\
Kecepatan alir (g/detik) & $8,02 \pm 0,73$ & $8,13 \pm 0,69$ & $25-40[41]$ \\
Sudut istirahat $\left({ }^{\circ}\right)$ & $32,65 \pm 1,20$ & $32,65 \pm 1,20$ & $2-4[29]$ \\
\hline Kandungan lembab (\%) & $2,64 \pm 0,43$ & $2,84 \pm 0,28$ & \\
\hline
\end{tabular}
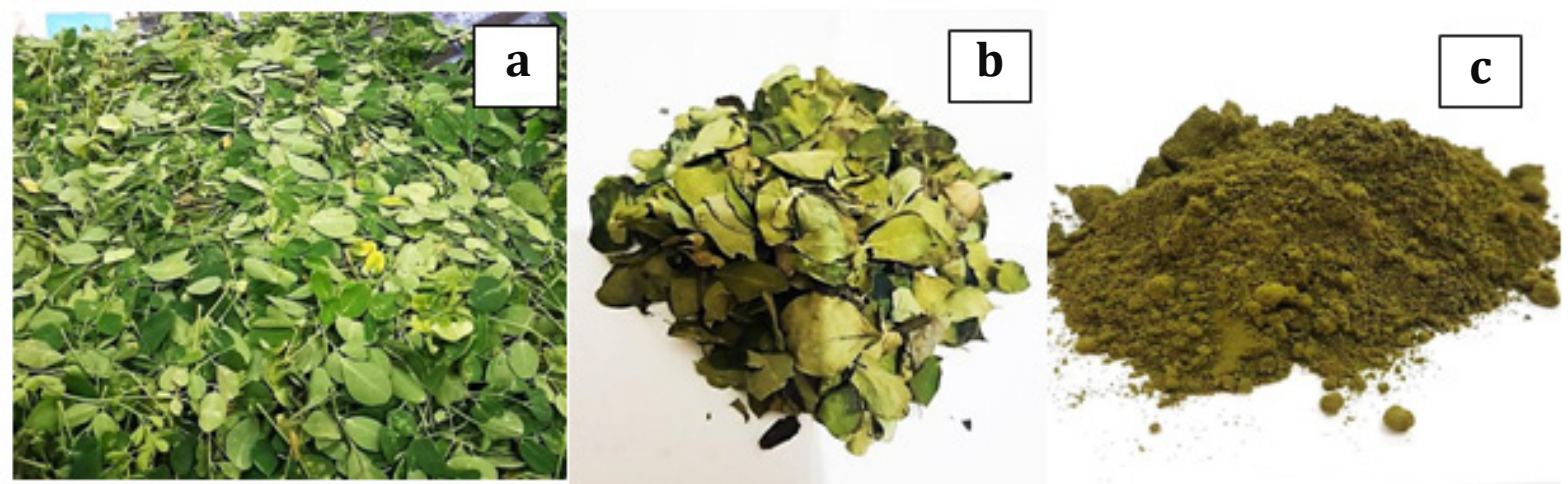

Gambar 1. Daun kelor segar (a); kering (b); dan serbuk kering (c)
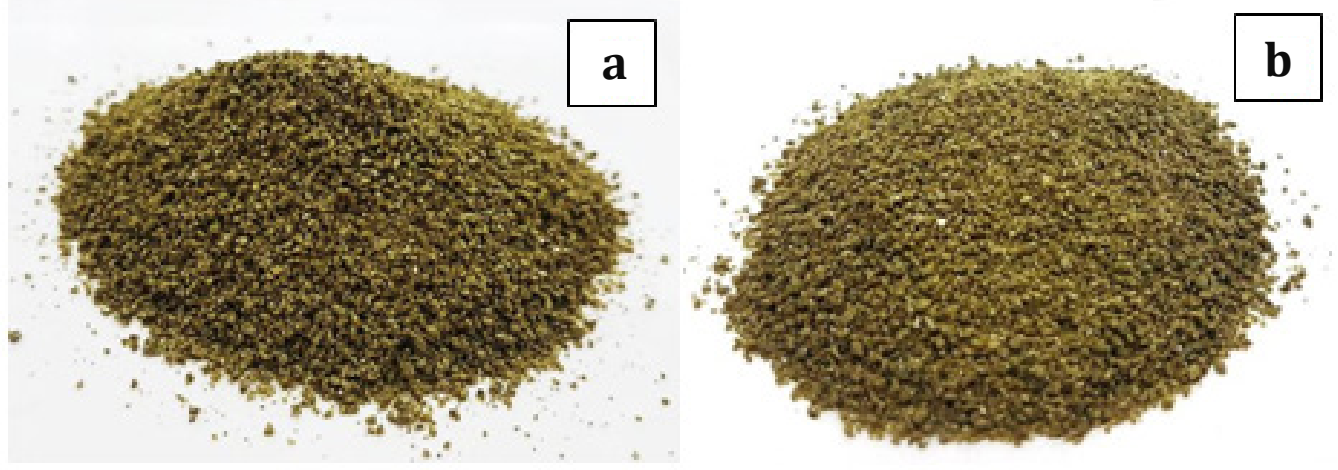

Gambar 2. Granul sereal daun kelor Formula 1 (a) dan Formula 2 (b)

bahwa granul berwarna hijau tua, dengan rasa manis dan aroma melon. Granul memiliki ukuran partikel yang seragam, tidak terdapat bongkahan granul dengan ukuran yang besar. Tabel 2 dan Gambar 2 menunjukkan hasil uji organoleptis granul.

Ukuran partikel dan distribusi ukuran partikel berpengaruh terhadap kemampuan alir granul saat proses pengisian ke dalam kemasan primer [25]. Distribusi ukuran partikel juga mempengaruhi suspendabilitas partikel tidak larut untuk tetap terdispersi secara seragam dalam suatu pembawa cair. Kondisi tersebut berkaitan dengan keseragam kandungan bahan aktif dalam sereal saat dikonsumsi oleh konsumen [26]. 
Ukuran serbuk yang sangat kecil (fines) dalam jumlah banyak tidak diharapkan, karena dapat menyebabkan segregasi. Segregasi menyebabkan serbuk tidak dapat mengalir dengan baik, sehingga berdampak pada ketidakseragaman kandungan dalam sediaan. Semakin besar persentase fines dalam sediaan dapat menyebabkan gaya tarik menarik antar partikel semakin besar, sehingga granul lebih sulit mengalir. Pada analisis distribusi untuk menghitung rasio Hausner dan indeks kompresibilitas (Carr's index). Pengukuran rasio Hausner bermanfaat untuk memperkirakan aliran serbuk karena berhubungan dengan gesekan antar partikulat. Sementara itu, pengukuran indeks kompresibilitas juga bermanfaat menentukan karakteristik alir granul karena merupakan ukuran langsung terhadap kekuatan dan stabilitas ikatan antar partikel serbuk [18].

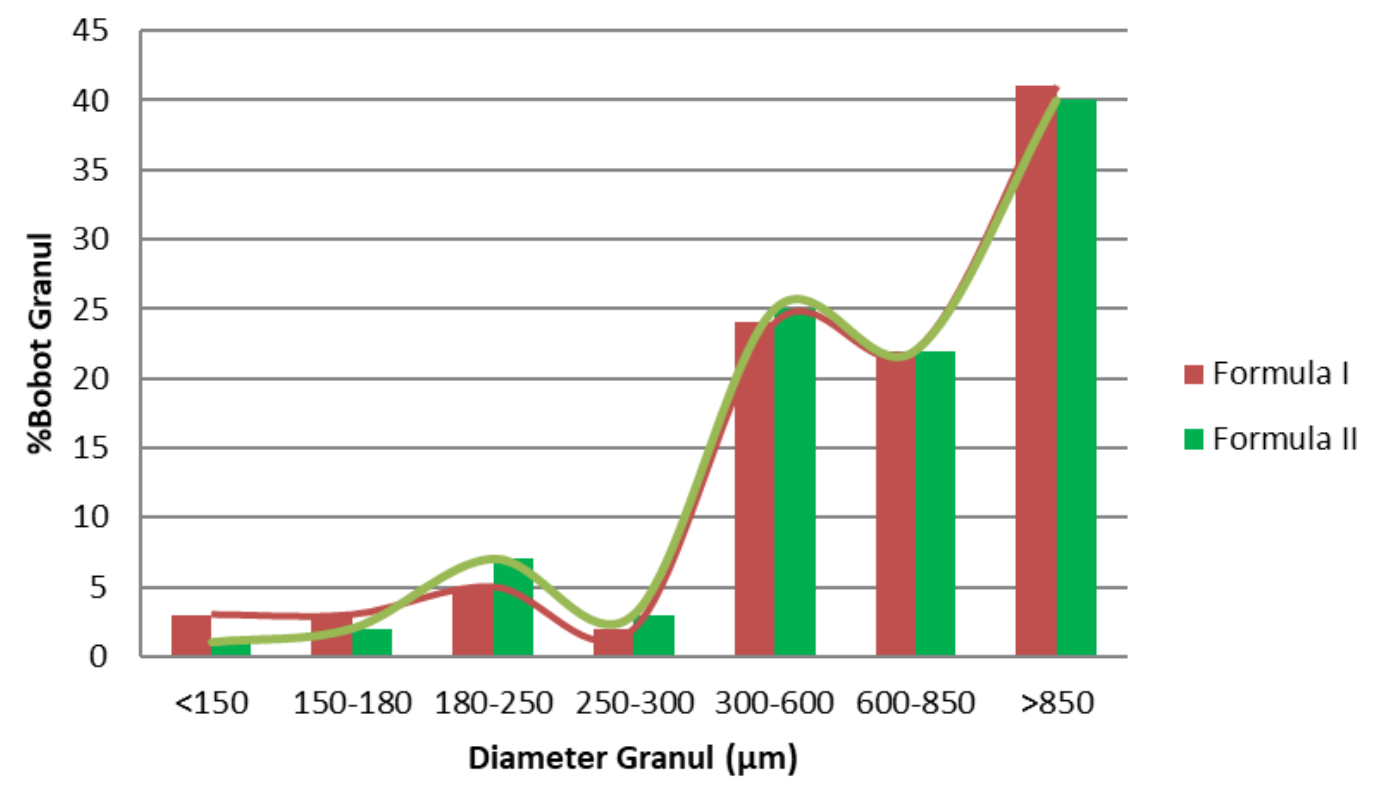

Gambar 3. Distribusi ukuran partikel granul sereal daun kelor Formula 1 dan Formula 2

ukuran partikel kedua formula sereal, diketahui bahwa proporsi terbesar granul berada pada ukuran partikel $>850 \mu \mathrm{m}$. Persentase rata-rata fines untuk formula 1 dan 2 berturut-turut adalah $2,5 \%$ dan $2 \%$. Kedua formula telah memenuhi persyaratan persen fines yaitu <20\% [26]. Grafik distribusi ukuran partikel sereal daun kelor formula 1 dan 2 ditunjukkan pada Gambar 3. Berdasarkan grafik tersebut, dapat disimpulkan bahwa kedua formula sereal daun kelor memiliki ukuran partikel yang seragam.

Hasil evaluasi bobot jenis nyata, bobot jenis mampat, rasio Hausner, dan indeks kompresibilitas sereal ditabulasikan pada Tabel 2. Bobot jenis merupakan rasio massa terhadap volume granul. Bobot jenis suatu padatan dapat memberikan gambaran tentang ukuran partikel dan sifat alir granul [26]. Bobot jenis nyata dan mampat yang diperoleh kemudian digunakan
Rasio Hausner dan indeks kompresibilitas formula 1 adalah $1,09 \pm 0,10$ dan $11,52 \pm 3,81 \%$. Sementara itu, nilai rasio Hausner dan indeks kompresibilitas formula 2 adalah 1,13 $\pm 0,07$ dan $11,19 \pm 5,64 \%$. Berdasarkan hal tersebut dapat disimpulkan bahwa kedua formula granul sereal daun kelor memiliki karakteristik aliran yang baik [27].

Kecepatan alir dan sudut istirahat merupakan parameter yang digunakan untuk menentukan sifat alir serbuk secara langsung. Kecepatan alir dapat mempengaruhi keseragaman kandungan suatu sediaan. Sifat alir yang buruk dapat menyebabkan ketidakseragaman dosis, sehingga efek terapetik sulit tercapai. Sudut istirahat menunjukkan karakteristik yang berhubungan dengan gesekan interpartikulat atau ketahanan gerakan antar partikel [28]. Hasil evaluasi kecepatan alir dan sudut istirahat 
granul sereal daun kelor ditampilkan pada Tabel 2. Kecepatan alir granul formula 1 yaitu $8,02 \mathrm{~g} /$ detik, sedangkan formula 2 adalah 8,13 g/detik. Kedua formula tersebut masuk dalam kategori mudah mengalir. Berdasarkan pengamatan sudut istirahat, diketahui sudut istirahat kedua formula adalah $32,65 \pm 1,20^{\circ}$. Kedua formula tersebut termasuk granul yang mudah mengalir ditinjau dari nilai sudut istirahatnya.

Kandungan lembab merupakan faktor kritis dalam formulasi sediaan granul dan serbuk. Peningkatan kadar lembab granul dan serbuk dapat menurunkan kemampuan serbuk untuk mengalir, namun peningkatan kadar lembab dapat meningkatkan kompresibilitas serbuk [29]. Kandungan lembab yang terlalu tinggi pada sediaan granul atau serbuk berdampak signifikan terhadap stabilitas kimia bahan aktif dan stabilitas mikrobiologi sediaan. Hasil evaluasi kandungan lembab menunjukkan bahwa kandungan lembab formula 1 adalah 2,64\%, sedangkan formula 2 adalah 2,84\%. Granul kedua formula telah memenuhi persyaratan kandungan lembab granul yaitu 2-4\%. Data kandungan lembab granul kemudian dianalisis statistik menggunakan uji-t bebas dan didapatkan hasil tidak terdapat perbedaan bermakna pada kedua formula ( $p>0,05)$. Berdasarkan data tersebut dapat disimpulkan bahwa perbedaan konsentrasi xanthan gum $(1,5 \%$ dan $2 \%)$ tidak berpengaruh signifikan terhadap kandungan lembab granul sereal daun kelor.

\subsection{Evaluasi sereal daun kelor setelah rekonstitusi}

Hasil evaluasi organoleptis sereal daun kelor

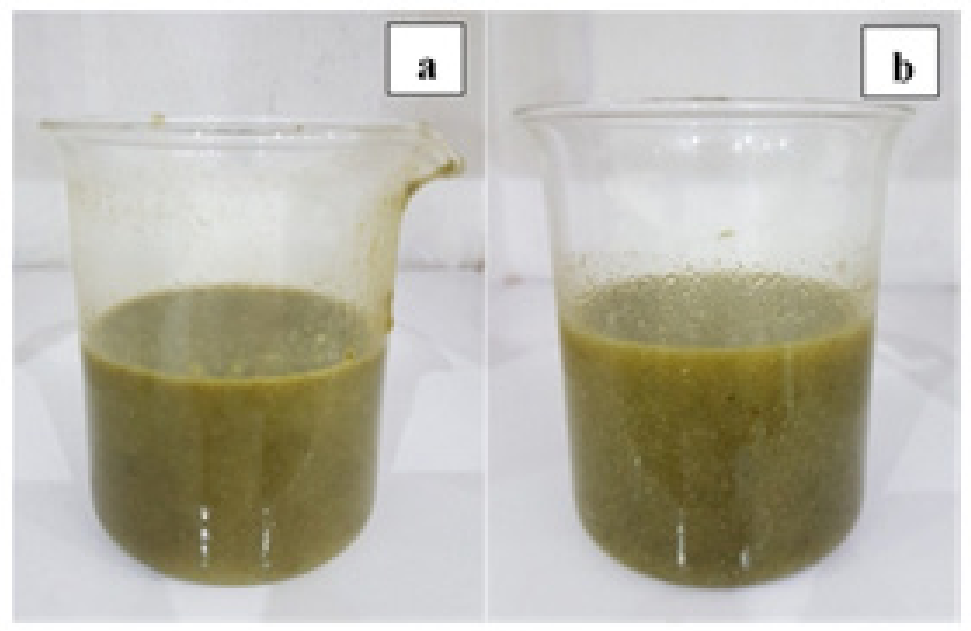

Gambar 4. Sereal daun kelor setelah rekonstitusi Formula 1 (a) dan Formula 2 (b)

Tabel 3. Hasil evaluasi karakteristik sereal daun kelor setelah rekonstitusi

\begin{tabular}{|c|c|c|c|c|}
\hline \multicolumn{2}{|l|}{ Parameter } & \multicolumn{2}{|l|}{ Formula } & \multirow[t]{2}{*}{ Persyaratan } \\
\hline & & $\mathrm{F} 1$ & $\mathrm{~F} 2$ & \\
\hline \multirow[t]{4}{*}{ Organoleptis } & Bentuk & Suspensi & Granul & Granul \\
\hline & Aroma & Melon & Melon & Melon \\
\hline & Rasa & Manis & Manis & Manis \\
\hline & Warna & Hijau kecoklatan & Hijau & Hijau \\
\hline \multicolumn{2}{|l|}{ Fines (\%) } & $2,50 \pm 1,00$ & $2,00 \pm 0,81$ & $<20[16]$ \\
\hline \multicolumn{2}{|l|}{ Rasio Hausner } & $1,09 \pm 0,10$ & $1,13 \pm 0,07$ & $1,00-1,25[41]$ \\
\hline \multicolumn{2}{|c|}{ Kompresibilitas (\%) } & $11,52 \pm 3,81$ & $11,19 \pm 5,64$ & $10-20[41]$ \\
\hline \multicolumn{2}{|c|}{ Kecepatan alir (g/detik) } & $8,02 \pm 0,73$ & $8,13 \pm 0,69$ & $4-10[42]$ \\
\hline \multicolumn{2}{|c|}{ Sudut istirahat $\left({ }^{\circ}\right)$} & $32,65 \pm 1,20$ & $32,65 \pm 1,20$ & $25-40[41]$ \\
\hline \multicolumn{2}{|c|}{ Kandungan lembab (\%) } & $2,64 \pm 0,43$ & $2,84 \pm 0,28$ & $2-4[29]$ \\
\hline
\end{tabular}


setelah direkonstitusi menunjukkan bahwa granul sereal terdispersi dalam bentuk suspensi halus berwarna hijau kecoklatan. Sereal daun kelor memiliki rasa yang manis dengan aroma melon. Hasil rekonstitusi sereal daun kelor ditunjukkan pada Gambar 4.

Pengamatan waktu dispersi sereal daun kelor dilakukan dengan mengukur waktu yang diperlukan oleh 30 g granul (1 sachet) terdispersi homogen dalam aquapurificata hangat. Waktu dispersi sediaan formula 1 dan 2 berturut-turut 8,44 dan 9,17 detik seperti yang dipaparkan pada Tabel 3. Kedua formula sereal daun kelor tersebut memenuhi persyaratan waktu dispersi sediaan granul oral yaitu $<5$ menit. Waktu dispersi sereal pada formula 2 lebih lama dibandingkan formula 1, karena konsentrasi xanthan gum sebagai suspending agent pada formula 2 lebih tinggi.

Peningkatan konsentrasi xanthan gum menyebabkan peningkatan kekentalan formula, sehingga air membutuhkan waktu yang lebih lama untuk berpenetrasi ke dalam struktur granul hingga seluruh granul terdispersi [9]. Kondisi ini menyebabkan peningkatan waktu dispersi pada sediaan dengan konsentrasi xanthan gum yang lebih tinggi. Hasil analisis statistik waktu dispersi sediaan dengan menggunakan uji-t bebas menunjukkan bahwa terdapat perbedaan siginifikan waktu dispersi kedua formula (p <0,05). Berdasarkan data tersebut dapat disimpulkan bahwa peningkatan konsentrasi xanthan gum (2\%) pada formula 2 menyebabkan waktu dispersi sediaan meningkat.

Pengujian $\mathrm{pH}$ sediaan sereal daun kelor bertujuan untuk memprediksi stabilitas dan aseptabilitas sediaan tersebut. $\mathrm{pH}$ stabil komponen antioksidan daun kelor berada pada rentang 4,00-9,00, sedangkan $\mathrm{pH}$ minuman fungsional secara umum berkisar antara 5,006,50 [30]. Hasil pengujian $\mathrm{pH}$ sediaan seral daun kelor formula 1 dan formula 2 berturutturut adalah 6,22 $\pm 0,06$ dan 6,25 $\pm 0,01$ seperti yang ditabulasikan pada Tabel 3. pH sediaan kedua formula tersebut memenuhi persyaratan yang telah ditetapkan yaitu 5,00-6,50 dan diprediksi mampu mempertahankan kandungan antioksidan daun kelor. Hasil analisis statistik dengan uji-t menunjukkan bahwa $\mathrm{pH}$ kedua formula sediaan tidak berbeda bermakna ( $p$ $>0,05)$.

Evaluasi viskositas dan karakteristik aliran serealdaunkelor dilakukan denganviskometercup and bob tipe stormer. Hasil evaluasi menunjukkan viskositas sediaan formula 1 dan formula 2 pada penambahan beban (shearing stress) $150 \mathrm{~g}$ adalah 136,93 dan 275,58 cps. Viskositas sediaan kedua formula memenuhi persyaratan yang ditetapkan yaitu 200-400 cps. Sediaan sereal daun kelor harus memiliki viskositas yang memadai untuk menjamin serbuk daun terdispersi merata setelah proses rekonstitusi. Hal ini berkaitan dengan homogenitas sediaan saat dikonsumsi. Hasil analisis menunjukkan bahwa viskositas formula 2 ( $2 \%$ xanthan gum) meningkat dua kali lipat dibandingkan formula 1 (1,5\% xanthan gum). Analisis statistik dengan uji-t bebas juga mendukung temuan tersebut. Peningkatan konsentrasi xanthan gum sebagai suspending agent dalam sereal daun kelor, secara signifikan ( $\mathrm{p}$ $<0,05)$ meningkatkan viskositas sediaan. Kondisi ini disebabkan oleh kemampuan xanthan gum untuk mengembang saat kontak dengan media aqueous [31]. Peningkatan konsentrasi xanthan gum menyebabkan jumlah molekul xanthan gum yang menarik air dan mengembang menjadi lebih besar, sehingga berdampak langsung pada viskositas sediaan.

Analisis terhadap rheogram kedua formula sereal daun kelor menunjukkan bahwa kedua formula memiliki karakteristik aliran pseudoplastis. Rheogram kedua formula ditunjukkan pada Gambar 5. Xanthan gum memiliki peranan besar dalam menentukan karakteristik aliran kedua formula sereal daun kelor. Dispersi xanthan gum dalam air menunjukkan karakteristik rheologi menyerupai gel dispersi molekular dan karakteristik pseudoplastis [32]. Hal ini menyebabkan sediaan sereal daun kelor yang dikembangkan dalam penelitian ini menunjukkan karakteristik 


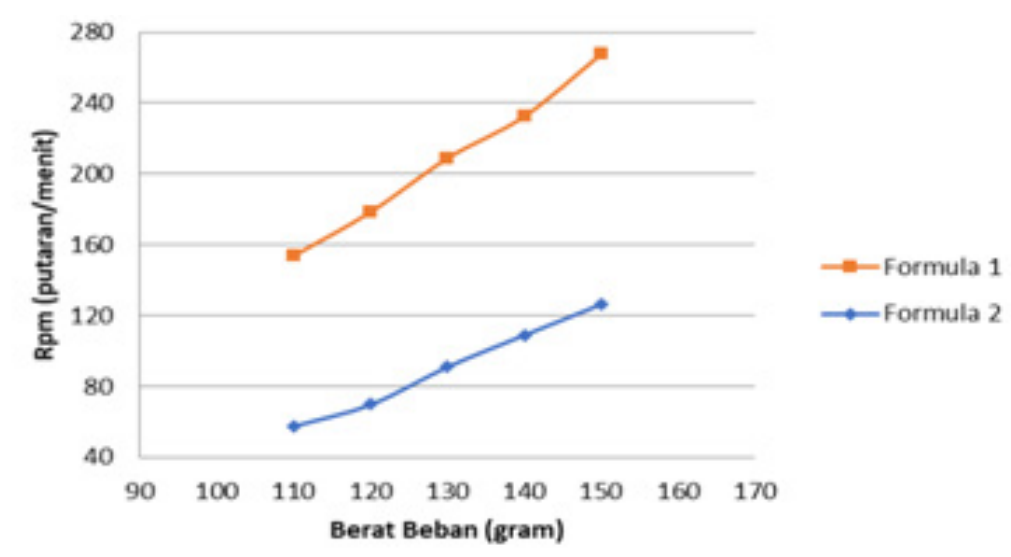

Gambar 5. Rheogram sifat alir sereal daun kelor formula 1 dan formula 2

Tabel 4. Hasil analisis proksimat dan kandungan logam $(\mathrm{Pb}$ dan $\mathrm{Cu}$ ) sereal daun kelor

\begin{tabular}{llll}
\hline Parameter & Hasil & Persyaratan & Keterangan \\
\hline Karbohidrat (\%) & 74,41 & Min. 60,0 & Memenuhi \\
\hline Kadar Protein (\%) & 11,71 & Min. 5,0 & Memenuhi \\
Kadar Lemak (\%) & 4,13 & Min. 7,0 & Tidak Memenuhi \\
\hline Serat Kasar (\%) & 1,70 & Maks. 0,7 & Tidak Memenuhi \\
Kadar Abu (\%) & 3,27 & Maks. 4,0 & Memenuhi \\
Kadar Air & 4,78 & Maks. 3,0 & Tidak Memenuhi \\
Timbal $(\mathrm{Pb}, \mathrm{mg} / \mathrm{kg})$ & Tidak terdeteksi & Maks. 2,0 & Memenuhi \\
Tembaga $(\mathrm{Cu}, \mathrm{mg} / \mathrm{kg})$ & 6,8 & Maks. 30,0 & Memenuhi \\
\hline
\end{tabular}

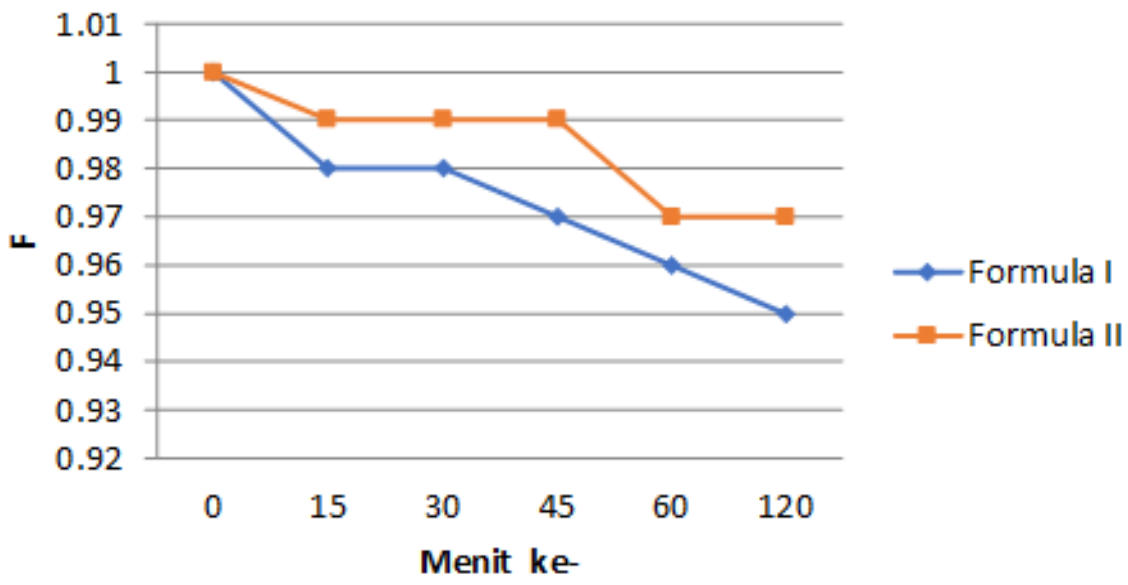

Gambar 6. Grafik volume sedimentasi sereal daun kelor Formula 1 dan Formula 2

pseudoplastis.

Dispersi sereal daun kelor dalam penelitian ini merupakan dispersi homogen partikel tidak larut dalam media aqueos. Volume sedimentasi merupakan salah satu parameter yang dapat digunakan untuk memprediksi stabilitas fisik sereal daun kelor setelah rekonstitusi. Sistem dispersi dikatakan ideal apabila laju sedimentasi lebih lama dan sedimen yang terbentuk mudah didispersikan kembali. Volume sedimentasi juga dapat digunakan untuk memprediksi derajat flokulasi suatu formula [33]. Sistem suspensi terflokulasi umumnya menunjukkan nilai volume sedimentasi (F) yang tinggi. Grafik volume sedimentasi sereal daun kelor pada berbagai waktu pengamatan ditunjukkan pada Gambar 6. Formula 1 menunjukkan nilai $\mathrm{F}<1$ serta lebih tidak stabil bila dibandingkan formula 2 . Volume 
sedimentasi sereal daun kelor formula 2 relatif stabil dan menunjukkan karakteristik mendekati suspensi ideal $(\mathrm{F}=1)$. Peningkatan konsentrasi xanthan gum memberikan dampak positif terhadap volume sedimentasi sediaan. Hal ini disebabkan semakin besar konsentrasi xanthan gum, maka viskositas sediaan akan mengalami peningkatan signifikan. Viskositas sediaan yang tinggi dapat menghambat sedimentasi serbuk daun kelor, sehingga keseragaman kandungan sediaan setelah rekonstitusi tercapai.

\subsection{Analisis proksimat dan kandungan logam}

Analisis proksimat dan kandungan logam dilakukan untuk mengevaluasi mutu sereal daun kelor yang dihasilkan sesuai dengan persyaratan SNI susu sereal. Analisis proksimatdan kandungan logam dilakukan pada formula 2, karena formula tersebut menunjukkan karakterisik fisik yang lebih baik ditinjau dari parameter viskositas dan volume sedimentasi dibandingkan formula 1. Analisis proksimat yang dilakukan meliputi penentuan kandungan protein, kadar lemak, serat kasar, kadar abu, kadar air, dan karbohidrat yang merujuk pada prosedur SNI 01-28911992 tentang cara uji makanan dan minuman. Analisis logam berat yang dilakukan meliputi analisis timbal $(\mathrm{Pb})$ dan tembaga $(\mathrm{Cu})$, merujuk pada prosedur SNI 01-2896-1998 tentang uji cemaran logam dalam makanan. Hasil analisis proksimat dan kandungan logam sereal daun kelor dipaparkan pada Tabel 4.

Analisis kandungan karbohidrat dalam sereal daun kelor didapatkan kadar 74,41\%. Nilai tersebut telah memenuhi persyaratan mutu SNI susu sereal (SNI 01-4270-1996) yaitu minimal $60,0 \%$. Tingginya kandungan karbohidrat disebabkan adanya tepung garut yang memiliki kandungan karbohidrat yang tinggi yaitu sebesar 24,4 g tiap $100 \mathrm{~g}$ tepung [34]. Hasil analisis kandungan protein didapatkan kadar 11,71\%, sehingga telah memenuhi persyaratan mutu SNI yaitu minimal 5,0\%. Hal tersebut disebabkan karena tanaman kelor memiliki kandungan protein yang tinggi sebesar $27,1 \%$ [35].
Hasil analisis kandungan lemak pada sereal daun kelor menunjukkan nilai sebesar 4,13\%. Kandungan lemak pada sereal dalam penelitian ini masih belum memenuhi persyaratan kadar lemak minimal susu sereal menurut SNI yaitu 7\%. Hal ini menunjukkan penggunaan kombinasi susu skim yang mengandung lemak 1\% dan susu soya mengandung lemak 2,5\% belum dapat meningkatkan kandungan lemak pada sereal. Penggunaan susu soya memberikan pengaruh lebih besar terhadap kandungan lemak, sehingga konsentrasi susu soya perlu ditingkatkan pada penelitian selanjutnya untuk memenuhi persyaratan kandungan lemak [11].

Hasil analisis kandungan serat kasar sereal daun kelor didapatkan nilai 1,70\%. Nilai tersebut belum memenuhi persyaratan mutu SNI susu sereal yaitu maksimal 0,7\%. Hal tersebut disebabkan tingginya kandungan serat yang terdapat pada daun kelor yaitu 19,2\% [36]. Xanthan gum juga diprediksi memiliki peranan dalam menyebabkan kadar serat kasar sereal yang cukup tinggi. Hal ini disebabkan kandungan serat yang tinggi dalam xanthan gum sebagai hidrokoloid dalam produk makanan [37]. Optimasi pada penelitian berikutnya perlu dilakukan untuk memperbaiki proses pengolahan serbuk daun kelor dan konsentrasi xanthan gum yang digunakan. Pendekatan ini dilakukan untuk memperoleh sereal dengan tekstur dan konsistensi yang aseptabel, serta kadar serat yang memenuhi persyaratan.

Kadar abu sereal daun kelor dalam penelitian ini adalah 3,27\%. Nilai tersebut telah memenuhi persyaratan mutu SNI 01-4270-1996 yaitu maksimal 4,0\%. Selain kadar abu, kadar air dalam sediaan merupakan faktor kritis yang berpengaruh terhadap stabilitas sediaan. Kandungan air yang terlalu tinggi dalam sediaan dapat menyebabkan peruraian bahan aktif, serta produk mudah ditumbuhi bakteri dan jamur [38]. Hasil analisis kadar air dalam sereal daun kelor didapatkan 4,78\%. Nilai tersebut tidak memenuhi persyaratan mutu SNI susu sereal, yaitu maksimal kadar air 3,0\%. Faktor 


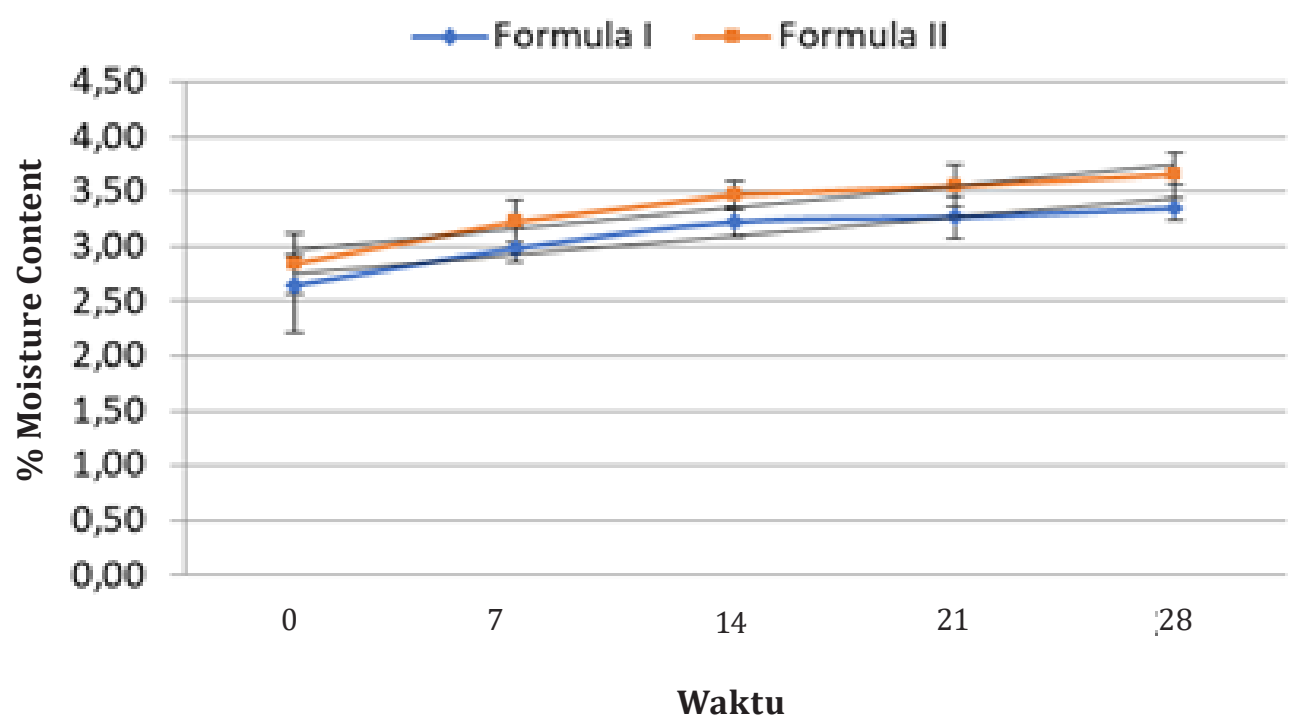

Gambar 7. Kandungan lembab sereal daun kelor Formula 1 dan Formula 2 selama penyimpanan 28 hari pada suhu kamar $\left(25-30^{\circ} \mathrm{C}\right)$

yang mempengaruhi tingginya kadar air dalam sediaan antara lain higroskopisitas beberapa komponen formula seperti susu soya, xanthan gum, sukrosa, dan perisa. Upaya yang dapat dilakukan untuk menekan kadar air pada pengembangan berikutnya adalah melakukan pengeringan komponen formula hingga diperoleh kadar air di bawah 4,0\%. Tujuan dari proses pengeringan tersebut adalah menurunkan kadar air dan aktivitas air dalam bahan awal dan produk, sehingga masa kadaluarsa produk menjadi lebih panjang [39]. Selain itu, desain kemasan yang kedap udara diharapkan juga dapat menanggulangi permasalahan tersebut.

Penentuan kandungan logam dalam produk sereal merupakan langkah penting untuk menjamin keamanan produk. Hal ini disebabkan sereal merupakan produk makanan yang umum dikonsumsi oleh manusia, terutama populasi di Asia Tenggara sebagai sumber energi. Akumulasi logam berat yang berasal dari tanaman dan komponen penyusun sereal dapat menyebabkan masalah kesehatan [40]. Hasil analisis sereal daun kelor menunjukkan bahwa kandungan logam $\mathrm{Pb}$ dan $\mathrm{Cu}$ berada di bawah batas maksimal persyaratan SNI susu sereal. Kondisi ini menunjukkan bahwa sereal daun kelor yang dihasilkan dalam penelitian ini memenuhi persyaratan keamanan produk pangan.

\subsection{Kandungan lembab sereal daun kelor selama penyimpanan pada suhu kamar}

Hasil analisis sereal daun kelor selama 28 hari pada penyimpanan suhu kamar menunjukkan tidak terjadi peningkatan kelembaban yang siginifikan, seperti ditunjukkan pada Gambar 7. Kandungan lembab sereal daun kelor formula 1 dan formula 2 pada titik akhir pengamatan menunjukkan nilai 3,35\% dan 3,65\%. Kandungan lembab kedua formula masih berada dalam rentang 2,0-4,0\%, sehingga dapat dinyatakan masih memenuhi persyaratan kandungan lembab sediaan granul. Komponen formula yang mudah menyerap kelembaban dan kemasan primer yang kurang optimal dalam menghalangi transmisi kelembaban diduga berperan meningkatkan kandungan lembab sediaan selama penyimpanan. Oleh karena itu, perlu memilih kemasan yang mampu melindungi produk dari pengaruh kelembaban dan perlu dilakukan penyeragaman kandungan lembab semua bahan yang ada dalam sediaan sebelum dilakukan pencampuran bahan.

\section{Kesimpulan}


Kesimpulan dari penelitian menunjukkan bahwa kedua formula granul mudah mengalir dan memiliki ukuran partikel yang seragam. Peningkatan konsentrasi xanthan gum pada formula 2 (2\%) berpengaruh signifikan terhadap peningkatan waktu dispersi dan viskositas dibandingkan formula $1(1,5 \%)$. Konsentrasi xanthan gum yang lebih tinggi pada formula 2 menghasilkan volume sedimentasi yang lebih tinggi dan stabilitas dispersi yang lebih baik dibandingkan formula 1 .

\section{Ucapan Terima Kasih}

Ucapan terima kasih disampaikan kepada LPPM Universitas Surabaya atas pendanaan penelitian ini dalam skema penelitian terapan tahun 2019-2020 dengan kontrak penelitian nomor 069/SP-Lit/LPPM-01/Int/FK/XII/2019.

\section{Daftar Pustaka}

1. Gupta S, Jain R, Kachhwaha S, Kothari SL. Nutritional and medicinal applications of Moringa oleifera Lam.-Review of current status and future possibilities. Journal of Herbal Medicine. 2018;11:1-11.

2. Chinwe I, Jose SM, Jaramillo J, Fausto D. Phytochemical and nutritional properties of dried leaf powder of Moringa Oleifera lam . from machala el oro province of ecuador. Asian Journal of Plant Science and Research. 2015;5(2):8-16.

3. Oyeyinka AT, Oyeyinka SA. Moringa oleifera as a food fortificant: Recent trends and prospects. Journal of the Saudi Society of Agricultural Sciences. 2018;17(2):127-36.

4. Shahidi F. Nutraceuticals, functional foods and dietary supplements in health and disease.Journal of Food and Drug Analysis. 2012;20(1):226-30.

5. Sohaimy SA El, Hamad GM, Mohamed SE, Amar $\mathrm{MH}$, Al-hindi RR. Biochemical and functional properties of Moringa oleifera leaves and their potential as a functional food. Global Advanced Research Journal of Agricultural Science.
2015;4(4):188-99.

6. Yusof YA, Etti CJ, Chin NL. Development of Nutraceutical Product. International Journal on Advanced Science, Engineering and Information Technology. 2015;5(3):50-5.

7. Lee CM, Chan YL, Gan YL, Tang TK, Tan CP, Lai OM. Physicochemical and sensory analysis of instant cereal beverage incorporated with corncob powder. Food Research International. 2018;2(5):453-9.

8. Gimeno E, Moraru CI, Kokini JL. Effect of Xanthan Gum and CMC on the Structure and Texture of Corn Flour Pellets Expanded by Microwave Heating. Cereal Chemistry. 2004;81(1):100-7.

9. Anil M, Durmus Y, Tarakci Z. Effects of different concentrations of guar, xanthan and locust bean gums on physicochemical quality and rheological properties of corn flour tarhana. Nutrition \& Food Science. 2020; 51(1): 137-50.

10. Rani KC, Parfati N, Putri P, Regina E. Pengembangan Nutraseutikal Sereal Daun Kelor (Moringa oleifera L.) dengan Tepung Garut (Maranta arundinaceae L.) sebagai Pengikat. Jurnal Farmasi Indonesia. 2019;1: 40-8.

11. Ahanian B, Pourahmad R, Mirahmadi F. Effect of substituting soy milk instead of skim milk on physicochemical and sensory properties of sesame ice cream. Advances in Environmental Biology. 2014;8(11):9-16.

12. Badan Standarisasi Nasional. Standar Nasional Indonesia: Susu Sereal. Jakarta: Badan Standarisasi Nasional;1996.

13. Rivai H, Nurdin H, Suyani H, Amri Bakhtiar. Pengaruh cara pengeringan terhadap mutu herba meniran (Phyllanthus niruri Linn.) Influence of drying methods to quality of meniran herb. Majalah Farmasi Indonesia. 2011;1(22):73-6.

14. Djarot P, Badar M. Formulation and Production of Granule From Annona Muricata Fruit Juice As Antihypertensive Instant Drink. International Journal of Pharmacy and Pharmaceutical Sciences. 2017;9(5):18.

15. da Cunha-Filho MSS, Gustmann PC, Garcia FS, Lima EM, de Sá-Barreto LCL. Development and physical evaluation of Maytenus ilicifolia 
effervescent granules using factorial design. Brazilian Journal of Pharmaceutical Sciences. 2014;50(2):243-50.

16. Okoye EI, Awotunde TO, Morales TG. Formulation and characterization of Moringa oleifera leaf granules. I: Micromeritic properties. Research Journal of Pharmacy and Technology. 2013;6(1):66-74.

17. Al-Mousawy J, Al-Hussainy Z, Alaayedi M. Formulation and evaluation of effervescent granules of ibuprofen. International Journal of Applied Pharmaceutics. 2019;11(6):66-9.

18. Shah RB, Tawakkul MA, Khan MA. Comparative evaluation of flow for pharmaceutical powders and granules. AAPS PharmSciTech. 2008;9(1):250-8.

19. Szumilo M, Belniak P, Swiader K, Holody E, Poleszak E. Assessment of physical properties of granules with paracetamol and caffeine. Saudi Pharmaceutical Journal. 2017;25(6):900-5.

20. Wati S, Saryanti D. Effervescent Granule Formulation of Bitter Melon Extract (Momordica charantia L .) with Gelatin as A Wet Granulation Binder. Journal of Nutraceuticals and Herbal Medicine. 2019;2(1):20-8.

21. Madhavi N, Kumar D, Naman S, Singh M, Singh PA, Bajwa N. Formulation and Evaluation of Novel Herbal Formulations Incorporated with Amla Extract for Improved Stability. Journal of Drug Delivery and Therapeutics. 2019;9(4):212-21.

22. Khandelwal P, Shah P. Formulation and Evaluation of Oral Herbal Granules for Asthma. International Journal of Pharmaceutical Sciences and Research. 2016;7(10):382-9.

23. Nadaf SJ, Salunkhe SS, Kamble PM. Formulation and evaluation of ciprofloxacin suspension using natural suspending agent. International Journal of Pharmaceutical Sciences and Research. 2014;5(03):63-70.

24. Departemen Kesehatan Republik Indonesia. Farmakope Hebal Indonesia. Jakarta: Departemen Kesehatan Republik Indonesia; 2008.

25. Osorio JG, Muzzio FJ. Effects of powder flow properties on capsule filling weight uniformity. Drug Development and Industrial Pharmacy.
2013;39(9):1464-75.

26. Allen L V, Ansel HC. Ansel's Pharmaceutical Dosage Forms and Drug Delivery Systems 10th Edition.Baltimore:Wolters Kluwer Health; 2014.

27. The United States Pharmacopeial Convention. The United States Pharmacopeia and The National Formulary. Rockville: The United States Pharmacopeial Convention; 2016.

28. Augsburger LL, Hoag SW. Pharmaceutical Dosage Forms - Tablets Vol. 2. New York: Informa Healthcare; 2008.

29. Crouter A, Briens L. The Effect of Moisture on the Flowability of Pharmaceutical Excipients. AAPS PharmSciTech. 2013;15(1):65-74.

30. Arabshahi-D S, Vishalakshi Devi D, Urooj A. Evaluation of antioxidant activity of some plant extracts and their heat, $\mathrm{pH}$ and storage stability. Food Chemistry. 2007;100(3):1100-5.

31. Zietsman S, Kilian G, Worthington M, Stubbs C. Formulation development and stability studies of aqueous metronidazole benzoate suspensions containing various suspending agents. Drug Development and Industrial Pharmacy. 2007;33(2):191-7.

32. Murphy EG, Regost NE, Roos YH, Fenelon MA. Powder and reconstituted properties of commercial infant and follow-on formulas. Foods. 2020;9(1):1-17.

33. Sinko P. Martin's Phycical Pharmacy And Pharmaceutical Sciences. Baltimore: Lippincott Williams \& Wilkins; 2011.

34. Ariani M, Ashari. Arah, Kendala dan Pentingnya Diversifikasi Konsumsi Pangan di Indonesia. Jurnal Agro Ekonomi. 2003;21(2):99-112.

35. Gopalakrishnan L, Doriya K, Kumar DS. Moringa oleifera: A review on nutritive importance and its medicinal application. Food Science and Human Wellness. 2016;5(2):49-56.

36. Id AB, Buso P, Radice $M$, Dissette V, Id IL, Gambari R. Moringa oleifera Leaf Extracts as Multifunctional Ingredients for " Natural and Organic " Sunscreens and Photoprotective Preparations. Molecules. 2018;23(3):664.

37. Fajardo V, González MP, Martínez M, SamaniegoVaesken M de L, Achón M, Úbeda N. Updated food 
composition database for cereal-based gluten free products in spain: Is reformulation moving on? Nutrients. 2020;12(8):1-17.

38. Erkmen and Bozoglu TF. Food Preservation by Reducing Water Activity. In Food Microbiology: Principles into Practice. 2016;44-58.

39. Guiné RPF. The Drying of Foods and Its Effect on the Physical-Chemical, Sensorial and Nutritional Properties. ETP International Journal of Food Engineering. 2018;4(2):93-100.

40. Wei J, Cen K. Contamination and health risk assessment of heavy metals in cereals, legumes, and their products: A case study based on the dietary structure of the residents of Beijing, China. Journal of Cleaner Production. 2020;260:110
41. The United States Pharmacopeial Convention. United States Pharmacopeia 40 National Formulary 35. 2017. Rockville: The United States Pharmacopeial Convention.

42. York P, Aulton M, MarriottC, Fell J, Attwood D, Pugh J.. Pharmaceutics: The Science of Dosage Form Design. 2001. London: Churchill Livingstone.

43. Abd El-Rahim E, Abd El-Gawwad A, Rabie M, El-Gammal R. Preparing New Beverage from Moringa oleifera Leaves. Journal of Food and Dairy Science. 2017;8(7):303-7.

44. Wagoner TB, Çakır-Fuller E, Shingleton R, Drake MA, Foegeding EA. Viscosity drives texture perception of protein beverages more than hydrocolloid type. Journal of Texture Studies. 2020;51(1):78-91. 